\title{
PENGAWASAN SUMBERDAYA PERIKANAN DALAM PENANGANAN ILLEGAL FISHING DI PERAIRAN PROVINSI MALUKU UTARA
}

\author{
Armain Naim \\ Staf Pengajar Faperta UMMU-Ternate, e-mail: armain_tte@yahoo.co.id
}

\begin{abstract}
ABSTRAK
Sektor perikanan merupakan salah satu leading sektor dalam pembangunan ekonomi Provinsi Maluku Utara, namun konstribusi sektor ini dirasakan belum optimal dikarenakan masih ada praktek penangkapan ikan yang tidak bertanggung jawab dan bertentangan dengan peraturan perundang-undangan, karena terjadi kehilangan sumberdaya yang cukup besar akibat illegal fishing. Metode penelitian deskriptif dengan studi kasus digunakan untuk memperoleh gambaran (deskripsi) lengkap tentang pengawasan sumberdaya perikanan dalam penanganan illegal fishing di Perairan Maluku Utara oleh Dinas Kelautan dan Perikanan. Metode analisis data adalah qualitative-descriptive analysis dengan tabulasi distribusi frekuensi. Hasil analisis menunjukan bahwa sarana dan prasarana pengawasan masih sangat terbatas dan tidak efektif digunakan untuk melakukan pengawasan sumberdaya ikan di daerah yang menjadi kewenangan pengelolaan perikanan Pemerintah Provinsi Maluku Utara, 66,6\% responden mengatakan sarana dan prasarana kurang efektif untuk digunakan dalam membantu penanganan illegal fishing di perairan Provinsi Maluku Utara, Pembangunan Pos Pengawasan di setiap Kabupaten/Kota belum berfungsi sebagaimana yang direncanakan, jumlah lokasi dan intensitas patroli di laut sangat terbatas dan sangat dipengaruhi oleh cuaca di Laut. Kegiatan siswasmas masih kurang disosialisasikan, partisipasi masyarakat nelayan $54 \%$ pernah melaporkan illegal fishing di daerahnya, 85,57\% mengatakan bahwa mereka bersedia kalau dilibatkan dalam rapat yang membahas mengenai illegal fishing. Upaya pengawasan dan penegakan hukum oleh aparat pengawas masih lemah, masih terdapat perbedaan persepsi dan pemahaman antar aparat pengawas bidang perikanan tentang produk peraturan perundang-undangan bidang perikanan.
\end{abstract}

Kata

Kunci: Illegal fishing, pengawasan pengelolaan perikanan

\section{PENDAHULUAN}

\subsection{Latar Belakang}

Kontribusi sektor perikanan dan kelautan di Provinsi Maluku Utara dalam pembangunan daerah, dan kesejahteraan masyarakat telah menunjukan peningkatan yang berarti. Hal ini dapat dilihat dari peningkatan sejumlah indikator pada tahun 2007 dibandingkan tahun 2006, seperti produksi perikanan dari 120.693,92 ton menjadi 131.678,82 ton, peningkatan jumlah nelayan dari 6.894 orang menjadi 8.378 serta peningkatan pendapatan asli daerah (PAD) Provinsi Maluku Utara dari Rp. 378.050.650,- sumberdaya perikanan, optimalisasi

menjadi Rp. 436.078.875.-. Namun demikian disadari bahwa pemanfaatan dan pengelolaan perikanan belumlah optimal dibandingkan dengan potensi yang dimiliki, yakni hanya sekitar baru $16 \%$ atau 828.180,00 ton/tahun dari potensi lestari (maximum sustainable yield) pada tahun 2007 (Dinas Perikanan dan Kelautan Provinsi Maluku Utara 2007).

Belum optimalnya pemanfaatan dan pengelolaan sumberdaya kelautan dan perikanan disebabkan di antaranya oleh praktek-praktek pemanfaatan dan pengelolaan yang tidak bertanggung jawab dan pelanggaran peraturan- 
peraturan, sehingga terjadi kehilangan sumberdaya yang cukup besar setiap tahunnya. Perairan Provinsi Maluku Utara, yang berbatasan dengan Samudera Pasifik, merupakan tempat yang tergolong memiliki kerawanan yang tinggi untuk illegal fishing. Hal ini karena Samudera Pasifik merupakan pintu masuk bagi kapal-kapal ikan dari negara tetangga, seperti Philipina, Thailand dan Taiwan. Kegiatan illegal fishing yang umum terjadi di perairan tersebut adalah penangkapan ikan tanpa izin, penangkapan ikan dengan mengunakan izin palsu, penangkapan ikan dengan menggunakan alat tangkap terlarang, penangkapan ikan pada daerah yang tidak sesuai dengan daerah yang diizinkan dan penangkapan ikan yang hasil tangkapannya tidak dilaporkan.

Pengawasan merupakan mata rantai penting dalam perang melawan perikanan illegal, unreported, unregulated (IUU). Tanpa pengawasan dan pengendalian di lapangan, praktek IUU akan semakin liar dan buas. Berhasilnya pengawasan sangat bergantung pada dua hal utama, yaitu peralatan pengawasan dan manusia pengawas. Kedua hal inilah yang membentuk suatu sistem pengawasan perikanan (Nikijuluw, 2008).

Dalam Undang-Undang Nomor 31 tahun 2004 tentang Perikanan sangat jelas dikatakan bahwa illegal fishing diganjar hukuman dan denda sepadan pelanggaran yang dilakukan. Namun fakta berbicara lain, hukuman dan denda tidak diterapkan semestinya. Ketidakjelasan lainnya adalah sanksi terhadap oknum birokrasi perizinan dan pengawas serta keamanan laut yang dengan sengaja melakukan pungutan di luar ketentuan atau meloloskan pelanggar dengan kongkalikong (Azizy, 2005).

Kendala lain dalam upaya penegakan hukum perikanan di Provinsi Maluku Utara adalah rendahnya partisipasi dan kesadaran warga, khususnya sebagaian masyarakat nelayan. Dalam melakukan kegiatan penangkapan ikan mereka menggunakan bahan-bahan yang berbahaya dan tidak sesuai peraturan perundangundangan yang berlaku. Selain itu mental pengusaha Indonesia, khususnya di Provinsi Maluku Utara, yang lebih senang berperan sebagai perantara atau broker bagi pengusaha asing (Philipina) dengan system management fee.

\subsection{Tujuan dan Manfaat Penelitian.}

Tujuan yang ingin dicapai dalam penelitian ini adalah :

1. Mengetahui kapasitas pengawasan perikanan di wilayah Provinsi Maluku Utara.
2. Menganalisis keefektivan pengawasan dalam menangani permasalahan IUU fishing.

3. Meningkatkan pengetahuan tentang Illegal Unreported Unregulated (IUU) fishing, partisipasi dan persepsi masyarakat tentang keefektifan dalam pengawasan di perairan Maluku Utara.

Manfaat dari penelitian ini adalah sebagai salah satu sumber informasi ilmiah kegiatan pengawasan sumberdaya perikanan dalam penanganan illegal fishing di Perairan Provinsi Maluku Utara.

\section{METODOLOGI PENELITIAN}

\subsection{Populasi dan Sampel}

Populasi dari penelitian ini adalah semua masyarakat nelayan yang berada di lokasi penelitian. Guna menghemat waktu, tenaga dan biaya, maka dari keseluruhan populasi tersebut diambil sampelnya dengan metode purposive sampling dengan kriteria:

1. Nelayan, pemimpin usaha penangkapan ikan (fishing master), nakhoda kapal ikan dan pemilik kapal ikan, sebanyak 30 orang;

2. Warga masyarakat pesisir dan anggota kelompok pengawas masyarakat (POKWASMAS) bidang perikanan tangkap sebanyak 30 responden.

Penelitian ini dilakukan di wilayah Provinsi Maluku Utara, dengan sampel pada Kabupaten Halmahera Utara, Kabupaten Halmahera Selatan, Kabupaten Halmahera Timur, Kabupaten Kepulauan Sula dan Kota Ternate dengan pertimbangan di 5 (lima) daerah ini paling banyak menangani kasus illegal fishing pada Pengadilan Negeri yang berada di wilayah administrasinya.

Penentuan sampel pada kelima Kabupaten/Kota tersebut dilakukan secara non probability random sampling. Penentuan sampel secara non probability random sampling didasarkan pada data unit populasi nelayan yang tidak memiliki izin atau yang melakukan kegiatan illegal fishing belum diketahui serta seluruh populasinya tidak mempunyai kesempatan yang sama untuk dijadikan sampel. Pengambilan sampel secara purposive sampling disesuaikan dengan tujuan penelitian. Ukuran sampel tidak dipersoalkan. Sampel yang diambil hanya yang sesuai dengan tujuan penelitian. Dengan kata lain, sampel yang dihubungi adalah sampel yang sesuai dengan kriteria tertentu yang ditetapkan berdasarkan tujuan penelitian.

Pengambilan data ini dilaksanakan pada bulan mei sampai bulan juni 2009 di kabupaten 
halmahera utara, kabupaten halmahera selatan dan kota ternate.

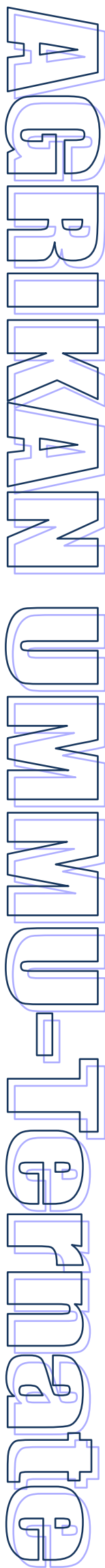

\subsection{Instrumen Penelitian}

Dalam penelitian kualitatif, seorang peneliti merupakan instrumen utama penelitian sehingga ia dapat melakukan penyesuaian sejalan dengan kenyataan-kenyataan yang terjadi dilapangan (Alsa, 2003). Jadi dalam penelitian ini yang menjadi instrument utama adalah peneliti. Sebagai penunjang keberhasilan penelitian, peneliti menggunakan instrumen pelengkap, yaitu: (1) panduan wawancara (interview guide); (2) catatan lapangan (field note); (3) alat-alat tulis; (4) tape recorder, dan (5) kamera.

\subsection{Prosedur Pengumpulan Data}

Metode pengumpulan data dalam penelitian ini adalah dengan cara sampling, yakni cara pengumpulan data dari sebagian populasi Adapun teknik pengumpulan data yang digunakan adalah sebagai berikut :

1. Wawancara Mendalam (In-Depth Interview),

Dalam melaksanakan wawancara, peneliti menggunakan panduan wawancara. Tujuan penggunaan panduan wawancara (interview guide) adalah agar fokus wawancara tidak keluar dari konteks penelitian. Dalam wawancara, penelii menggunakan tahapan sebagai beriukut :

a. Menetapkan responden yang akan diwawancarai.

b. Menyiapkan pokok-pokok masalah yang akan menjadi pokok pembicaraan dalam panduan wawancara. Pokok-pokok masalah sebagaimana yang dituangkan dalam panduan wawancara tersebut disusun berdasarkan urut-urutan dari pertanyaan yang memerlukan jawaban dengan pemikiran sederhana menuju pertanyaan yang memerlukan jawaban dengan pemikiran lebih kompleks.

c. Memulai atau membuka alur wawancara, yaitu pewawancara menyampaikan tentang tujuan wawancara kepada responden, kemudian berusaha menjalin hubungan yang harmonis dan santai.

d. Melangsungkan alur/arus wawancara, yaitu diawali dengan menyampaikan pertanyaan-pertanyaan ringan kemudian makin-lama makin mengerucut pada permasalahan-permasalahan krusial.

e. Mengkonfirmasikan hasil wawancara dengan responden yang diwawancarai dan mengakhirinya. Tahapan ini dilakukan dengan jalan menyampaikan secara lisan atas hasil wawancara yang sudah dicatat dalam catatan lapangan yang bersifat sementara, dan responden tinggal mengya-kan atau mengoreksi jawaban yang sudah disampaikan.

f. Menuliskan hasil wawancara pada catatan lapangan secara cermat dalam bentuk catatan lapangan yang lebih rapi sebagai bahan analisis data.

Sedangkan alat wawancara yang digunakan dalam pengambilan data pada penelitian ini adalah: (1) panduan wawancara, (2) catatan lapangan, (3) alat-alat tulis, serta (4) Tape Recorder.

2. Observasi, yaitu pengumpulan data yang dilakukan dengan cara mengadakan pengamatan langsung terhadap fenomenafenomena yang tampak pada objek-objek penelitian di lapangan.

3. Kuesioner, untuk Nelayan, Pemimpin penangkapan ikan (fishing master), Nakhoda kapal ikan, masyarakat pesisir dan anggota POKWASMAS lingkup perikanan tangkap

4. Dokumentasi, yaitu dengan melakukan pencatatan, pengambilan gambar dilapangan melalui pemotretan, serta fotocopy data sekunder dari instansi terkait.

Jenis data yang akan dikumpulkan dalam penelitian nantinya terdiri dari data primer dan data sekunder. Untuk melihat sikap masyarakat nelayan dalam pengawasan sumberdaya perikanan yang sesuai dengan peraturan perundang-undangan yang berlaku, dibutuhkan data primer dari masyarakat nelayan, selain itu dilakukan wawancara langsung dengan 18 (delapan belas) orang informan kunci (key informant) terutama yang berhubungan dengan usaha perikanan tangkap.

Data sekunder adalah data yang diperoleh dari instansi terkait. Laporan penelitian, literature, karya ilmiah, dokumentasi maupun para informan lainnya yang terkait dengan penelitian ini. Data sekunder yang dikumpulkan meliputi gambaran umum wilayah penelitian, kebijakan pendukung serta bahan-bahan pustaka yang menjadi landasan teori.

\subsection{Metode Analisis Data}

Sesuai dengan rancangan penelitian (case study) dan jenis data yang akan dikumpulkan, maka metode analisis data adalah qualitativedescriptive analysis dengan tabulasi distribusi frekuensi dengan rumus. 
III. HASIL DAN PEMBAHASAN

\subsection{Pengawasan Sumberdaya Perikanan Pada Dinas Kelautan dan Perikanan Provinsi Maluku Utara}

Pelaksanaan kegiatan pengawasan sumberdaya perikanan di Perairan Provinsi Maluku Utara oleh Dinas Kelautan dan Perikanan Provinsi Maluku Utara dilaksanakan melalui 4 (empat) program, yaitu :

\subsubsection{Peningkatan Sarana Dan Prasarana Pengawasan}

Dalam rangka mendukung pelaksanaan pengawasan dan pengendalian Sumberdaya Kelautan dan Perikanan di Perairan Provinsi Maluku Utara, Dinas Kelautan dan Perikanan Provinsi Maluku Utara mempunyai program peningkatan sarana dan prasarana pengawasan, yang dilaksanakan melalui berbagai kegiatan diantaranya adalah :

\section{a. Pengadaan Speed Boat}

Dari tahun 2003 sampai dengan 2008 Dinas Kelautan dan Perikanan telah mengadakan speed boat pengawasan sebanyak 4 (empat ) unit, dengan ukuran masing-masing panjang 12 meter 1 unit dan panjang 9 meter 3 unit, yang ditempatkan masing-masing di Kabupaten Halmahera Selatan 1 unit, Halmahera Utara 1 unit dan Kota Ternate 2 unit. Dengan ukuran dan jumlah speed boat yang ada kegiatan pengawasan di Laut, khususnya kegiatan patroli pada daerah-daerah penangkapan sangat terbatas dan sangat rentan terhadap perubahan cuaca. Kondisi ini menyebabkan kegiatan pengawasan perikanan oleh Dinas Kelautan dan Perikanan Provinsi Maluku Utara tidak dapat menjangkau pada daerahdaerah yang merupakan wilayah pengelolaan perikanan Provinsi Maluku Utara, yakni perairan hingga jarak 4 sampai dengan 12 mil dari pesisir pantai. Data di atas menunjukan bahwa sarana yang tersedia tidak sebanding dengan luas wilayah yang menjadi wilayah kerja Dinas Kelautan dan Perikanan dalam rangka melaksanakan fungsi pengawasan, hal ini juga sejalan dengan pendapat aparat penegak hukum terhadap ketersediaan sarana dan prasarana. Masalah ini dikonfirmasi oleh $66,66 \%$ aparatur pengawas yang mengatakan bahwa sarana dan prasarana pengawasan di Provinsi Maluku Utara sangat kurang dalam menunjang pelaksanaan penegakan hukum dalam bidang perikanan (Gambar 1).

Speed boat pengawasan yang dimiliki Dinas Kelautan dan Perikanan Provinsi Maliku Utara tidak efektif digunakan untuk melakukan pengawasan sumberdaya ikan.

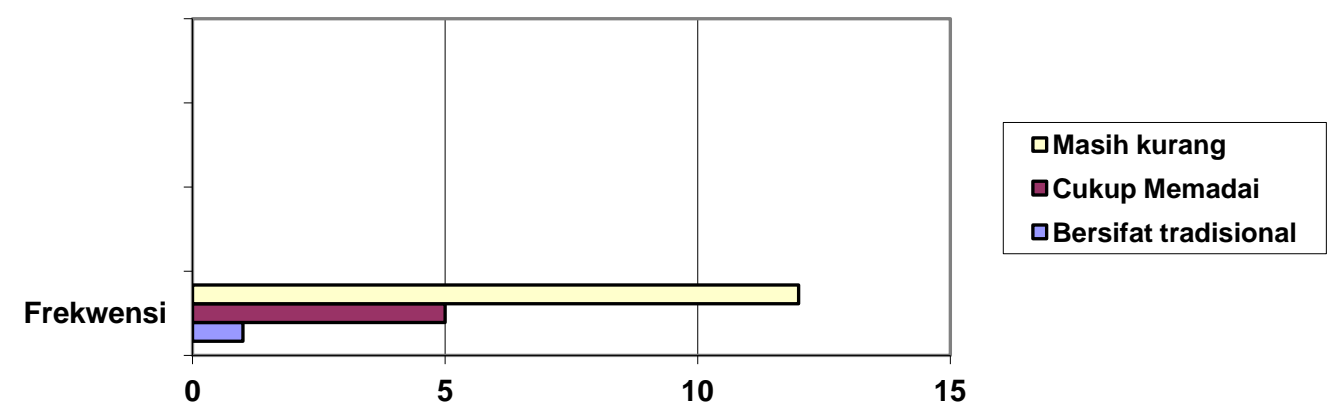

Gambar 1. Histogram Pendapat Aparat Penegak Hukum Tentang Kondisi Sarana Dan Prasarana Pengawasan Sumberdaya Perikanan Di Provinsi Maluku Utara

\section{b. Pembangunan Pos Pengawasan}

Sebanyak 8 Pos Pengawasan serta perlengkapannya telah dibungun oleh Dinas Kelautan dan Perikanan Provinsi Maluku Utara sebagai upaya untuk mendukung kelancaran dalam pelaksanaan tugas Pengawasan dan Pengendalian Sumberdaya Kelautan dan Perikanan, khususnya untuk pemantauan dan memperpendek rantai pelaporan kegiatan pengawasan dari masyarakat (Tabel 1). Pos Pengawasan tersebut berada di Kabupaten Halmahera Utara 1 unit, Halmahera Timur 1 unit, Halmahera Barat 1 unit Halmahera Selatan 1unit, Kepulauan Sula 1 unit, Kota Ternate 1 unit dan Kota Tidore Kepulauan unit.

Pos pengawasan di Provinsi Maluku Utara belum berjalan sesuai dengan tujuan dan sasaran pembangunan. Hal ini karena tidak ditunjang dengan penyediaan sumberdaya manusia dan anggaran yang sesuai seperti dikatakan oleh $66 \%$ responden. 
Pos pengawasan yang belum beroperasi meliputi ; Kabupaten Halmahera Timur, Kabupaten Halmahera Barat, Kabupaten Halmahera Tengah, Kabuapeten Kepulauan Sula dan Kota Tidore Kepulauan. Kondisi ini sangat menghambat informasi/komunikasi antar petugas pengawas maupun dengan masyarakat nelayan terkait dengan illegal fishing yang terjadi di daerahnya.

Tabel 1. Perkembangan Pos Pengawasan di Provinsi Maluku Utara Tahun 2008

\begin{tabular}{|c|c|c|c|c|c|c|c|}
\hline \multirow{2}{*}{ No } & \multirow{2}{*}{ KABUPATEN/KOTA } & \multirow{2}{*}{ KECAMATAN } & \multicolumn{5}{|c|}{ TAHUN } \\
\hline & & & 2004 & 2005 & 2006 & 2007 & 2008 \\
\hline 1. & Halmahera Utara & Tobelo & 1 & - & - & - & - \\
\hline 2. & Halmahera Barat & Jailolo & - & 1 & - & - & - \\
\hline 3. & Halmahera Timur & Maba & - & 1 & - & - & - \\
\hline 4. & Halmahera Tenganh & Pulau Gebe & - & 1 & - & - & - \\
\hline 5. & Halmahera Selataan & Bacan & 1 & - & - & - & - \\
\hline 6. & Kepulauan Sula & Sanana & - & 1 & - & - & - \\
\hline 7. & Kota Ternate & Kota Ternate Utara & - & 1 & - & - & - \\
\hline \multirow[t]{2}{*}{8.} & Kota Tidore kep & Tidore & - & 1 & - & - & - \\
\hline & & Jumlah & 2 & 6 & - & & \\
\hline
\end{tabular}

\section{c. Alat Komunikasi}

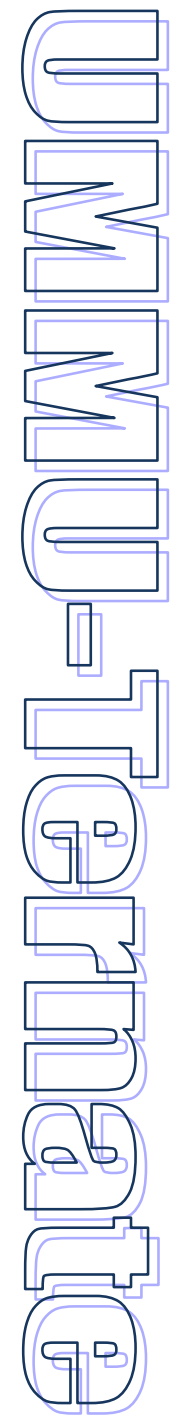
pada Tabel 2.
Dalam rangka meningkatkan koordinasi dan pelaporan serta pertukaran informasi/berita dari masyarakat pengawas maupun dari aparat pengawas di lapangan dengan aparat penyidik diperlukan dukungan sarana komunikasi yang dapat dioperasionalkan dengan jangkauan seluruh wilayah Provinsi Maluku Utara pada khususnya dan wilayah Indonesia pada umumnya. Sampai dengan tahun 2008 Dinas Kelautan dan Perikanan telah mengadakan sarana komunikasi yang meliputi Radio SSB sebanyak 25 Unit, Repiter sebanyak 3 unit dan Radio HT sebanyak 130 unit yang tersebar pada pos pengawasan, anggota Kelompok Masyarakat Pengawas (POKWASMAS) serta petugas pengawas di 8 Kabupaten/Kota di di Provinsi Maluku Utara.

Keberadaan alat komunikasi dalam mendukung kegiatan pengawasan perikanan di Provinsi Maluku Utara belum berfungsi sebagaimana yang ditargetkan hal ini dipengaruhi oleh belum operasionalnya Pos Pengawasan, yang terkait dengan ketersediaan sumberdaya listirk dan sumberdaya manusia.

Pengadaan sarana komunikasi pada Dinas Kelautan dan Perikanan Provinsi Maluku Utara tidak efektif digunakan dalam membantu kegiatan pengawasan.

Jenis dan jumlah alat komunikasi untuk pengawasan sumberdaya perikanan disajikan
Tabel 2. Jenis dan Jumlah Sarana Komunikasi pada Tahun 2008

\begin{tabular}{|c|c|c|}
\hline NO & Jenis Sarana Komunikasi & Jumlah \\
\hline 1 & Radio SSB & 25 \\
\hline 2 & Radio HT & 130 \\
\hline 3 & Repiter & 3 \\
\hline & Jumlah & 158 \\
\hline
\end{tabular}

Sumber: DKP Prov. Maluku Utara

\section{d. Sarana/Perlengkapan Pengawasan}

Disamping sarana prasarana pokok sebagaimana tersebut di atas, juga telah diadakan peralatan/perlengkapan pengawas bagi tenaga pengawas khususnya yang berada di tingkat lapangan. Peralatan pengawas tersebut diantaranya : GPS Mapping, net gauge, Seragam Pengawas, Kostum Anggota POKWASMAS, Laptop bagi penyidik, kendaraan roda dua untuk petugas pada Pos Pengawas, kamera digital dan alat selam.

Peralatan/perlengkapan pengawas tersebut sangat membantu dalam kegiatan pengawasan sumberdaya perikanan di Provinsi Maluku Utara, namun kurang didukung oleh sumberdaya aparatur yang memadai. Hal ini mengakibatkan sarana/perlengkapan pengawas kurang efektif digunakan dalam pengawasan.

Secara keseluruhan, sumber daya pengawasan yang ada di Provinsi Maluku dapat dilihat pada Tabel 3. 
Tabel 3. Perkembangan Sarana dan Prasarana Pengawasan Sumberdaya Perikanan Dan Kelautan Provinsi Maluku Utara pada Tahun 2008

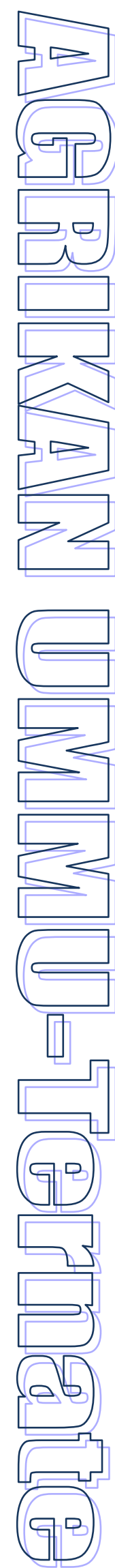

\begin{tabular}{|c|c|c|}
\hline No & Uraian & Jumlah \\
\hline 1. & $\begin{array}{ll}\text { Pesonil Pengawasan } \\
\text { - } & \text { Tenaga PPNS Pusat dan Daerah } \\
\text { - } & \text { Tenaga Teknis } \\
\text { - } & \text { Pengawas Kapal Ikan }\end{array}$ & $\begin{array}{l}8 \text { Orang } \\
14 \text { Orang } \\
6 \text { Orang }\end{array}$ \\
\hline 2 & $\begin{array}{ll}\text { Prasarana yang dimiliki } \\
\text { - } & \text { Dermaga PPP Bacan } \\
\text { - } & \text { Dermaga PPP Tobelo } \\
\text { - } & \text { Dermaga PPN Ternate } \\
\text { - } & \text { Pos Pengawasan } \\
\text { - } & \text { Satker Pengawasan } \\
\text { - } & \text { Stasion Pengawasan di Dinas Perikanan \& Kelautan Provinsi }\end{array}$ & $\begin{array}{l}1 \text { buah } \\
1 \text { buah } \\
1 \text { buah } \\
8 \text { unit } \\
1 \text { unit } \\
1 \text { unit }\end{array}$ \\
\hline 3. & $\begin{array}{ll}\text { Sarana Penunjang Kegiatan Pengawasan } \\
- & \text { Speed Boat Dinas Perikanan dan Kelautan Provinsi Maluku Utara } \\
- & \text { Radio Komudikasi / HT } \\
\text { - } & \text { Kelompok Masyarakat Pengawas (POKWASMAS) } \\
\text { - } & \text {-Radia Komunikasi SSB }\end{array}$ & $\begin{array}{l}4 \text { unit } \\
130 \text { Unit } \\
75 \text { Klmpok } \\
25 \text { unit }\end{array}$ \\
\hline
\end{tabular}

\subsubsection{Peningkatan Pengawasan Dan Pengendalian Sumberdaya Perikanan}

Program ini dilaksanakan melalui 2 (dua) kegiatan yakni :

a. Operasi Pengawasan Sumberdaya Perikanan di Laut

Operasi pengawasan ini ditujukan untuk mengawasi operasional kapal ikan di laut, meliputi; aspek perizinan, ketaatan jalur penangkapan, alat tangkap, alat bantu penangkapan dan pemasangan rumpon di laut. Operasi pengawasan secara reguler dilakukan dengan speed boat milik Dinas Kelautan dan Perikanan Provinsi Maluku Utara dan dibantu dengan kapal patroli miliki Departemen kelautan dan Perikanan.

Dalam melakukan operasi pengawasan sumberdaya perikanan, Dinas Kelautan dan Perikanan Provinsi Maluku Utara dibantu oleh anggota Direktorat Polisi Perairan POLDA Maluku Utara dan Pangkalan Angkatan Laut Ternate.

Operasi pengawasan dengan menggunakan speed boat berukuran panjang 12 meter dan 9 meter sangat terbatas jangkauannya dan tidak dapat menjangkau daerah penangkapan (rumpon) pada laut terbuka yang berada pada jarak 4 sampai dengan 12 mil merupakan wilayah pengelolaan perikanan provinsi.

Intensitas operasi pengawasan dengan menggunakan speed boat sangat dipengaruhi oleh faktor cuaca. Untuk menjangkau daerah penangkapan ikan (fishing ground) pelagis besar yang rata-rata berada pada jarak di atas 12 mil diperlukan kapal patroli yang relatif besar.

Hasil Operasi bersama POLAIR Ternate dan LANAL Ternate selama tahun 2008 telah memeriksa sebanyak 205 kapal perikanan. Dari 205 Kapal perikanan yang diperiksa, 12 kapal selanjutnya menjalani proses hukum (di-adhoc) ke Pelabuhan karena melakukan pelanggaran, sedangkan $193 \mathrm{kapal}$ dibiarkan melakukan kegiatan perikanan karena dokumennya sah.

Operasi pengawasan di laut yang menjadi tugas Dinas Kelautan dan Perikanan Provinsi Maluku Utara belum efektif dilaksanakan karena kegiatan patroli sangat terbatas pada daerah pesisir kurang lebih 4 mil dari pantai. Speed boat yang berukuran kecil tidak cukup untuk melaksanakan tugas tersebut.

b. Pengawasan Ketaatan Kapal Perikanan di Pelabuhan

Operasi pengawasan ketaatan kapal di pelabuhan perikanan dilakukan terhadap ketaatan kapal melakukan pendaratan ikan di pelabuhan dan ketaatan kapal mengisi surat laik operasional (SLO). Berdasarkan hasil pengawasan di beberapa pelabuhan rata-rata ketaatan kapal masih rendah. Menyikapi hal tersebut telah dilakukan koordinasi dengan Sub Bagian Perizinan Dinas Kelautan dan Perikanan Provinsi Maluku Utara, agar kapal- 
kapal yang tidak melakukan pendaratan sesuai dalam izin untuk tidak direkomendasikan berpangkalan di Pelabuhan tersebut dalam perizinan selanjutnya.

Pengawasan ketaatan kapal di Pelabuhan perikanan dan Pangkalan Pendaatan Ikan di Provinsi Maluku Utara belum berjalan dengan baik dan tidak efektif akibat belum beroperasinya Pangkalan
Pendaratan Ikan (PPI), disamping itu belum adanya penempatan petugas pengawas pada Pangkalan Pendaratan Ikan (PPI) oleh Dinas Kelautan dan Perikanan di Kabuaten/Kota, yang terdiri dari PPI Kabupaten Halmahera Timur, PPI Kabupaten Halmahera Barat, PPI Kabuapaten Halmahera Tengah, PPI Kabupaten Kepulauan Sula da PPI Kota Tidore Kepulauan.

Tabel 4. Jumlah Bulanan Kapal Yang Mendapat SLO dari 4 Pelabuhan Perikanan di Maluku Utara Pada Tahun 2008

\begin{tabular}{|c|c|c|c|c|c|c|c|c|c|c|c|c|c|c|}
\hline \multirow{2}{*}{ No } & \multirow{2}{*}{ Lokasi } & \multicolumn{12}{|c|}{$B \cup L A N$} & \multirow{2}{*}{$\mathrm{Jml}$} \\
\hline & & Jan & Feb & Mart & Apr & Mei & Jun & Juli & Agst & Sept & Okt & Nov & Des & \\
\hline 1 & PPN Ternate & 42 & 63 & 60 & 60 & 68 & 55 & 80 & 73 & 73 & 90 & 149 & 111 & 924 \\
\hline 2 & PPP Bacan & - & - & - & - & 136 & 106 & 77 & 102 & 112 & 59 & 144 & 60 & 796 \\
\hline 3 & PPP Tobelo & - & - & - & - & - & - & - & 4 & 5 & 5 & 5 & - & 19 \\
\hline \multirow[t]{2}{*}{4} & PPI DUFA2 & - & 15 & 63 & 26 & 54 & 44 & 23 & 26 & 42 & 33 & - & - & 326 \\
\hline & Jumlah & 42 & 78 & 123 & 86 & 258 & 205 & 180 & 205 & 232 & 187 & 298 & 171 & 2,065 \\
\hline
\end{tabular}

Sumber: DKP Prov. Maluku Utara

\subsubsection{Pengembangan Siswasmas}

Salah satu program prioritas dalam pengawasan sumberdaya perikanan oleh Dinas Kelautan dan Perikanan Provinsi Maluku Utara adalah pengembangan Sistem Pengawasan Berbasis masyarakat (siswasmas). Program ini dilaksanakan melalui pembentukan POKWASMAS. Kegiatan ini adalah melibatkan masyarakat untuk turut berpartisipasi dalam melakukan pengawasan terhadap sumberdaya kelautan dan perikanan.

Penggalangan siswasmas dilakukan melalui POKWASMAS yang digerakkan dan dibina oleh tenaga pengawas di tingkat Kabupaten/Kota. Bentuk pembinaan berupa peningkatan teknis pengawasan dan pemberian stimulant kepada kelompok-kelompok tersebut berupa perlengkapan pengawas (radio komunikasi, pakaian seragam/kostum pengawas, mesin tik, dan GPS).

Sampai dengan tahun 2008 telah terbentuk 75 POKWASMAS yang tersebar di 9 Kabupaten/Kota. Melalui program ini nelayan dijadikan sebagai bagian dari pengawasan, mereka sebagai informan atau melaporkan tentang kejadian-kejadian yang terjadi di daerah penangkapan. Mereka juga dapat melakukan pencegahan dan mengusir pelaku illegal fishing dari perairan Maluku Utara. Dengan mengandalkan armada perikanan rakyat yang ada saat ini, Provinsi Maluku Utara sulit memanfaatkan sumberdaya perikanan yang dimilikinya secara optimal, walaupun Maluku
Utara pada saat sekarang ada sekitar 4.565 kapal perikanan, ternyata dari jumlah armada perikanan tersebut, sekitar $37 \%$ adalah armada perahu tanpa motor dan $36 \%$ adalah perahu bermotor tempel dengan kekuatan 40 PK. Sisanya adalah 1.250 atau 27\% adalah kapal motor. Dari 1.250 kapal motor, 1.102 diantaranya adalah kapal motor yang berukuran kurang dari 10 GT. Sedangkan kapal motor yang berukuran 20 - 30 GT hanya ada 59 buah.

Dengan struktur armada penangkapan ikan seperti ini, sangat sulit bagi nelayan Maluku Utara menguasai dan memanfaatkan sumberdaya ikan yang dimilikinya. Nelayan Maluku Utara hanya bisa berkonsentrasi di sekitar perairan pesisir. Mereka sulit menjangkau perairan yang lebih jauh untuk menangkap ikan yang lebih tinggi nilai ekonominya. Ketidak mampuan nelayan ini tentu saja adalah peluang dan kesempatan bagi nelayan asing untuk masuk dan menjarah sumberdaya yang tidak dimanfaatkan oleh nelayan Maluku Utara, oleh karena itu, sebagai tindakan pre-emptive terhadap illegal fishing, Maluku Utara harus mengembangkan kekuatan dan kemampuan dalam memanfaatkan sumberdaya perikanan dalam bentuk pengembangan kapal perikanan skala besar, pengembangan perikanan skala industri, serta motorisasi dan modernisasi armada perikanan rakyat.

Pengembangan armada perikanan skala besar, dengan kapal-kapal 20 sampai dengan 30 GT patut dilakukan untuk mengisi kekosongan 
armada perikanan Maluku Utara di Laut Maluku, Laut Halmahera, Laut Seram dan Samudera Pasifik. Adanya armada perikanan berskala besar di perairan Maluku Utara merupakan penghalang bagi armada perikanan asing masuk ke perairan Maluku Utara. Untuk itu mereka perlu diberikan bantuan armada penangkapan ikan dan dilatih untuk mengoperasikan armada penangkapan dengan ukuran di atas 30 GT dengan peralatan navigasi yang canggih.

Program SISWASMAS di Provinsi Maluku Utara masih kurang disosialisasikan ke masyarakat nelayan Hal ini dikonfirmasi oleh $55 \%$ nelayan yang menyatakan belum pernah mendengar tentang program SISWASMAS dan $35 \%$ orang menyatakan cukup memahami program tersebut (Tabel 5). Program sistem pengawasan sumberdaya kelautan dan perikanan berbasis masyarakat (SISWASMAS) yang dilaksanakan oleh Dinas Kelautan dan perikanan Provinsi Maluku Utara belum efektif karena anggota POKMASWAS hanya berada di sekitar pesisir dengan armada yang kecil dan tidak dapat menjangkau perairan di atas 12 mil.

Tabel 5. Pengetahuan Masyarakat Nelayan Terhadap Program SISWASMAS

\begin{tabular}{clcc}
\hline No. & \multicolumn{1}{c}{ Indikator/Tanggapan } & Frekwensi & Persentase (\%) \\
\hline 1. & Mengetahui SISWASMAS & 47 & 42,73 \\
2. & Tidak Mengetahui SISWASMAS & 60 & 54,55 \\
3. & Tidak menjawab & 3 & 2,73 \\
\hline \multicolumn{2}{c}{$\mathrm{N}$} & 110 & 100 \\
\hline Sumber : & Data Primer
\end{tabular}

Tabel 6. Perkembangan POKWASMAS di Provinsi Maluku Utara Sampai dengan Tahun 2008

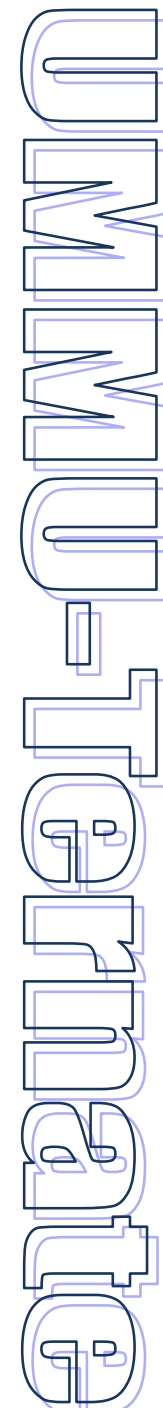

\begin{tabular}{|c|c|c|c|c|c|c|c|c|}
\hline \multirow{2}{*}{ KABUPATEN/KOTA } & \multicolumn{7}{|c|}{ Tahun } & \multirow{2}{*}{ Jumlah } \\
\hline & 2002 & 2003 & 2004 & 2005 & 2006 & 2007 & 2008 & \\
\hline Halmahera Barat & 1 & - & - & 2 & - & - & & 3 \\
\hline Halmahera Tengah & 1 & - & 2 & 3 & - & - & & 6 \\
\hline Halmahera Timur & 1 & 1 & - & 2 & - & - & & 3 \\
\hline Halmahera Selatan & 2 & 1 & 1 & 6 & 2 & 2 & & 14 \\
\hline Halmahera Utara & 2 & 1 & - & 8 & - & - & 15 & 24 \\
\hline Kepulauan Sula & 1 & - & 2 & 2 & 1 & 1 & 5 & 12 \\
\hline Kota Tidore Kepulauan & - & 1 & - & 2 & - & 2 & - & 5 \\
\hline Kota Ternate & - & - & - & 3 & - & 2 & - & 5 \\
\hline JUMLAH & 8 & 4 & 5 & 28 & 3 & 7 & 20 & 75 \\
\hline
\end{tabular}

Sumber : Data Primer

\subsubsection{Penaatan Dan Penegakan Hukum}

Program ini dilaksanakan melalui kegiatan rapat koordinasi aparatur penegak hukum dan program Penanganan Tindak Pidana Perikanan. Kegiatan rapat koordinasi dilakukan untuk membahas permasalahan yang dihadapi di lapangan dan menyamakan persepsi dan pemahaman tentang produk peraturan perundangundangan bidang perikanan.

Permasalahan yang paling menonjol dalam rapat koordinasi adalah permasalahan perizinan dan perbedaan penafsiran terhadap peraturan perundang-undangan contohnya; penerbitan izin usaha penangkapan ikan oleh Dinas Kelautan dan perikanan Kabupaten/Kota hanya menggunakan Peratuaran Daerah Kabupaten/Kota tanpa melakukan cek fisik kapal sebagaimana peraturan menteri kelautan dan perikanan RI. Orientasi sistem perizinan sebagai alat pemberi izin dan alat untuk mendapatkan uang/pendapatan asli daerah (PAD) menyebabkan illegal fishing sangat berpeluang terjadi. Banyak izin telah diberikan oleh Dinas Kelautan dan Perikanan, baik provinsi maupun Kabupaten/Kota yang tidak jeli dan kerap menyimpang dari peraturan perundangundangan, khususnya terkait dengan asal usul kapal/bendera kapal, cek fisik kapal, ketentuan Anak Buah kapal (ABK), daerah penangkapan dan pelabuhan pangkalan.

Permasalahan lain yang sering muncul dalam penyidikan dan pemberkasan perkara adalah perbedaan pemahaman dan penafsiran terhadap peraturan perundang-undangan, berdasarkan hasil wawancara dengan Penyidik Pegawai Negeri Sipil (PPNS) Perikanan di Dinas Kelautan dan Perikanan Provinsi Maluku Utara diperoleh data bahwa terjadi perbedaan penafsiran dalam undang-undang perikanan sebagai berikut : penerapan tindak pidana ringan dalam kasus perikanan, hal ini terjadi pada Kejaksaan Tinggi Ternate yang menggunakan sistem pemeriksaan cepat seperti halnya tindak 
pidana ringan (contoh pelanggaran lalu-lintas) yang menggunakan kitab undang-undang hukum acara pidana (KUHAP) pada kasus pelanggaran daerah penangkapan, sedangkan oleh penyidiki pegawai negeri sipil (PPNS) perikanan menggunakan sistem pemeriksaan singkat dan bukan tindak pidana ringan, pemahaman terhadap pelanggaran Surat Laik Operasional (SLO) oleh penyidik polisi perairan (POLAIR) dikenakan pasal pidana sedangkan oleh penyidik pegawai negeri sipil (PPNS) perikanan menerapkan pasal pelanggaran administrasi.

Tabel 7. Tanggapan Aparatus Pengawasan Sumberdaya Perikanan Terhadap Peraturan Perundang-Undangan di Provinsi Maluku Utara.

\begin{tabular}{cccc}
\hline No & Indikator/Tanggapan & Frekwensi & Persentase (\%) \\
\hline 1. & Belum memadai & 9 & 50,00 \\
2. & Sudah memadai & 8 & 44,44 \\
3. & Tidak menjawab & 1 & 5,6 \\
\hline & $\mathbf{N}$ & 18 & 100 \\
\hline
\end{tabular}

Dari tahun 2006 sampai dengan tahun 2008 telah dilakukan penanganan pelanggaran terhadap tindak pidana perikanan sebanyak 64 kasus, dengan rincian sebagai berikut:

Tabel 8. Penanganan Tindak Pidana Perikanan Tahun 2006 Sampai Dengan Tahun 2008 Di Provinsi Maluku Utara

\begin{tabular}{clc}
\hline No & \multicolumn{1}{c}{ Jenis Pelanggaran } & Jumlah Kasus \\
\hline 1 & Pelanggaran tanpa Izin & 15 \\
2 & Pelanggaran alat tangkap & 2 \\
3 & Pelanggaran fishing ground & 27 \\
4 & Pelanggaran LBP/SLO & 5 \\
5 & Pelanggaran SIB & 9 \\
6 & Pelanggaran ABK & 4 \\
7 & PEmalsuan Dokumen & 1 \\
8 & PEmbiusan & 1 \\
\hline \multicolumn{2}{c}{ Total } & 64 \\
Sumber: Data Primer
\end{tabular}

Dari 64 kasus yang yang diproses ke Pengadilan sebanyak 59 kasus dan telah diputus oleh pengadilan dan 5 kasus dilakukan pembinaan karena tidak terbukti melakukan tindak pidana hanya bersifat pelanggaran administrasi.

Tabel 9. Perkembangan tindak pidana perikanan selama tahun 2005 sampai dengan 2008

\begin{tabular}{ccc}
\hline No. & Tahun & Jumlah Pelanggaran \\
\hline 1. & 2005 & 9 \\
2. & 2006 & 13 \\
3. & 2007 & 18 \\
4. & 2008 & 33 \\
\hline Sumber : Data Primer
\end{tabular}

Penanganan tindak pidana perikanan yang diproses hukum dari tahun 2005 sampai dengan tahun 2008 menunjukan peningkatan, keadaan ini dapat dihubungkan dengan tingginya partisipasi masyarakat nelayan dalam melaporkan tindak pidana yang terjadi di daerahnya, namun kondisi ini belum optimal karena kasus yang ditemukan hanya berada pada wilayah pesisir pantai, akibat keterbatasan sarana dan prasarana serta aparat pengawas, selain itu tuntutan dan sanksi yang diberikan sangat rendah dibandingkan dengan kerugian yang ditimbulkan, sehingga kurang membuat efek jera kepada pelaku. Hal ini menunjukan bahwa kegiatan penegakan hukum yang dilakukan oleh Dinas Kelautan dan Perikanan Provinsi Maluku Utara belum efektif dalam penanganan illegal fishing di perairan Provinsi Maluku Utara.

\subsection{Partisipasi Nelayan dalam Pengawasan Sumberdaya Perikanan di Perairan Provinsi Maluku Utara}

Keterbatasan sarana dan prasarana serta jumlah personil pengawas yang menjadi kendala utama dalam mencapai kinerja pengawasan di Provinsi Maluku Utara dapat diminimalisir dengan memanfaatkan nelayan baik sebagai informan maupun sebagai penghalau masuknya pelaku illegal fishing di perairan Provinsi Maluku Utara.

Tingkat partisipasi nelayan di Provinsi Maluku Utara dalam pengawasan sumberdaya perikanan cukup tinggi, hal ini dapat dilihat dari hasil kuesioner bahwa 67,04\% nelayan akan melaporkan ke aparatur pengawasan apabila melihat kegiatan illegal fishing dan 18,18\% akan menegur dan menasehati.

Tingginya partisipasi masyarakat nelayan dalam melaporkan tindak pidana perikanan yang terjadi di daerahnya, dapat dihubungkan dengan peningkatan kasus tindak pidana perikanan yang diproses oleh aparat penegak hukum bidang 
perikanan di Provinsi Maluku Utara selama tahun 2005 sampai dengan tahun 2008, sebagaimana pada Tabel 10.

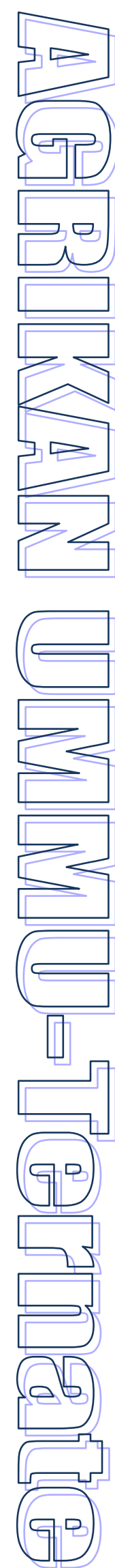

Tabel 10. Perkembangan Penanganan Kasus Tindak Pidana Perikanan di Provinsi Maluku Utara

\begin{tabular}{cc} 
Tahun & Jumlah Pelanggaran \\
\hline 2005 & 9 \\
2006 & 18 \\
2007 & 13 \\
2008 & 33 \\
\hline
\end{tabular}

Sumber : Data Primer

Partisipasi nelayan di Provinsi Maluku Utara dalam upaya pengawasan sumberdaya perikanan ditunjukan pula oleh kepedulian masyarakat nelayan dalam upaya pencegahan illegal fishing melalui kuesioner yang menunjukan bahwa $60,91 \%$ nelayan pernah mendiskusikan masalah illegal fishing dengan temannya, hal ini dapat disebabkan oleh kegiatan illegal fishing sudah sangat mengganggu aktivitas dan pendapatan masyarakat nelayan, sesuai hasil kuesioner bahwa 98\% masyarakat nelayan mengatakan bahwa illegal fishing di Maluku Utara sudah sangat mengganggu.

Histogram pada Gambar 2.a. menunjukan bahwa bahwa $63,64 \%$ nelayan berpendapat bahwa untuk mengatasi kegiatan illegal fishing di Maluku Utara diperlukan kerjasama antara aparat pemerintah dan masyarakat nelayan, disamping itu diperoleh data bahwa 89 orang dari 110 responden atau $85,57 \%$ mengatakan bahwa mereka bersedia kalau dilibatkan dalam rapat yang membahas mengenai illegal fishing.

Gambar 2.b. menunjukan bahwa, Keterlibatan masyarakat nelayan dalam upaya membantu pemerintah melakukan pengawasan sumberdaya perikanan cukup dipahami oleh masyarakat nelayan di Provinsi Maluku Utara. Hal ini sejalan dengan program SISWASMAS yang dilaksanakan oleh Dinas Kelautan dan Perikanan Provinsi Maluku Utara dan sosialisasi Keputusan Menteri Kelautan dan Perikanan Nomor: 58/MEN/2001 tentang Tata Cara Pelaksanaan Sistem Pengawasan Masyarakat Dalam Pengelolaan dan Pemanfaatan Sumberdaya Kelautan dan Perikanan.

Tingginya Partisipasi nelayan dalam pengawasan sumberdaya perikanan ditunjang oleh pemahaman masyarakat nelayan terhadap peraturan perundang-undangan di bidang Perikanan. Dari hasil kuisioner menunjukkan bahwa mayoritas nelayan $(64,55 \%)$ mengetahui tentang undang-undang perikanan dan kaitannya dengan penanganan illegal fishing, hal ini dapat terlihat pada Gambar 2.c.

Pada umumnya peraturan yang terdapat dalam undang-undang perikanan telah diketahui oleh nelayan di lokasi penelitian. Pengetahuan tentang undang-undang perikanan diketahui melalui instansi terkait yang mengadakan sosialisasi juga informasi dari sesama nelayan.

Dari hasil penelitian menunjukkan bahwa sekitar $67 \%$ pengetahuan tentang UndangUndang Perikanan diketahui melalui sosialisasi dari instansi terkait dan sekitar 7,27 \% diketahu melalui media. Hal ini terjadi mengingat kepemilikan media elektronik belum dimiliki oleh semua nelayan melihat status ekonomi mereka yang masih rendah. Pengetahuan nelayan tentang undang-undang perikanan ini sangat sinkron dengan hasil penelitian bahwa $88,9 \%$ petugas pengawas perikanan telah memberikan sosialisasi undang-undang perikanan kepada masyarakat nelayan (Gambar 2.d.).

Dari hasil sosialisasi undang-undang perikanan yang dilaksanakan oleh instansi perikanan menunjukan bahwa $63,75 \%$ nelayan menyatakan cukup memahami materi undangundang perikanan yang disampaikan (Gambar 2.e.).

Pengetahuan dan pemahaman undangundang perikanan oleh nelayan ini ditunjukkan dengan kemampuan nelayan dalam mendeteksi kapal-kapal ikan yang melakukan penangkapan ikan yang bertentangan dengan undang-undang perikanan yakni $69,09 \%$ menyatakan pernah melihat kegiatan perikanan yang bertentangan dengan undang-undang di daerah mereka Gambar 2.f).

\subsection{Upaya Pengawasan dan Penegakan Hukum Oleh Aparat Penegak Hukum di Provinsi Maluku Utara}

Pengawasan yang berhasil sangat bergantung pada sumberdaya manusia. Secanggih apapun sarana pengawasan, itu tidak akan berarti jika sumberdaya manusia tidak memiliki kapasitas dan komitmen untuk melakukan pengawasan dengan benar dan sesuai dengan aturan.

Kegiatan pengawasan dan penegakan hukum oleh aparat pengawas bidang perikanan di Provinsi Maluku Utara belum optimal. Pengakuan 18 orang aparat pengawas bidang perikanan atau $100 \%$ responden bahwa kegiatan pengawasan di perairan Provinsi Maluku Utara belum dapat menjangkau seluruh wilayah perairan yang menjadi kewenangan pengelolaan 
perikanan Pemerintah Daerah Provinsi Maluku Utara. Pengawasan dan patroli di lapangan, dari jumlah lokasi dan intensitasnya masih sangat terbatas. Oleh karena itu, fasilitas, personil, anggaran dan sistem insentif perlu dirumuskan kembali. Disamping itu koordinasi antar instansi terkait dalam penanganan illegal fishing, baik preventif maunpun represif perlu ditingkatkan.

Pencuri hanya bisa ditangkap jika ada polisi di lapangan atau pencuri akan menghentikan niatnya jika tahu kalau ada polisi di sekitarnya. Polisi yang menangkap pencuri

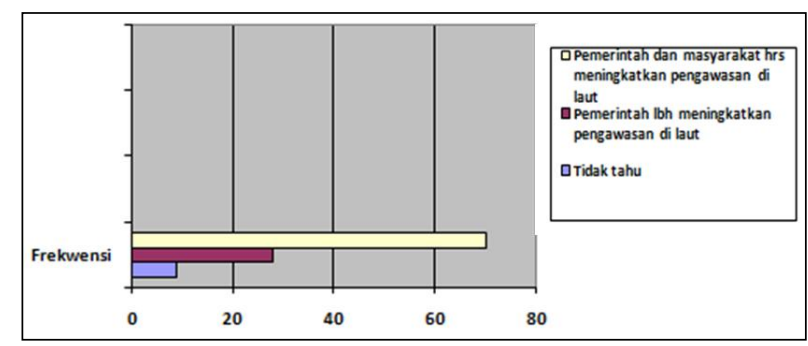

a.

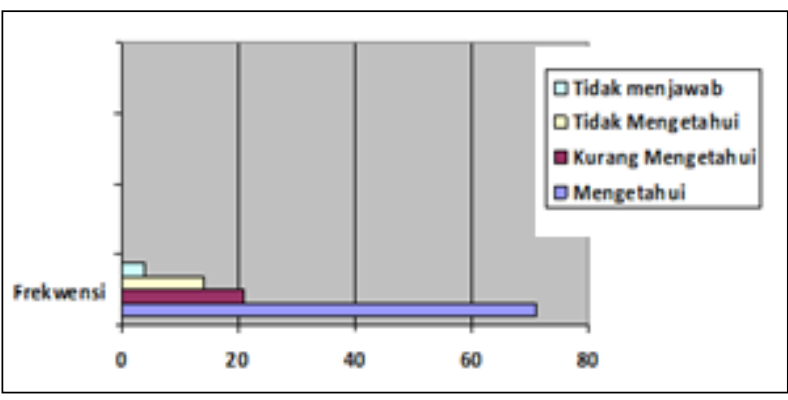

c.

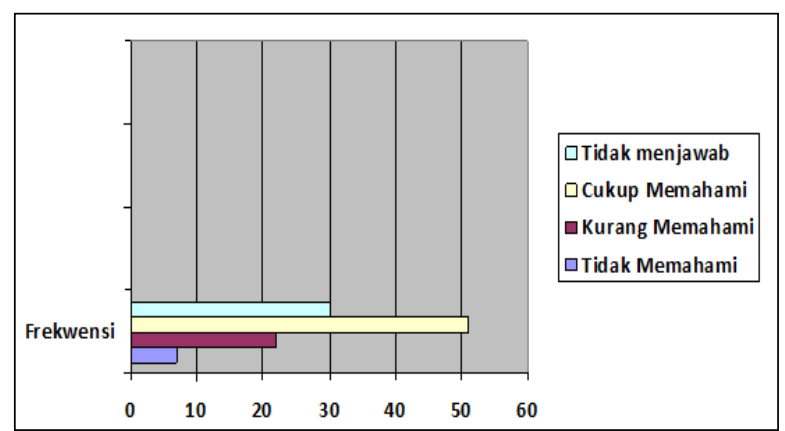

e. patut diberi penghargaan meskipun itu sudah merupakan tugas dan kewajibannya. Namun, sebaliknya polisi juga bisa tergoda untuk bekerja sama dengan pencuri, jika ini terjadi, maka polisi pun harus diberi sanksi.

Penegakan hukum dalam penanganan illegal fishing di Provinsi Maluku Utara patut dilakukan juga melalui perbaikan sistem perizinan. Oleh karena itu, dengan sistem perizinan yang lebih baik maka peluang berbuat kesalahan dapat dikurangi.

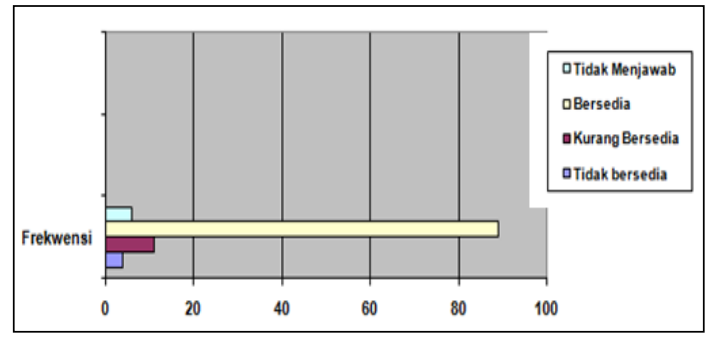

b.

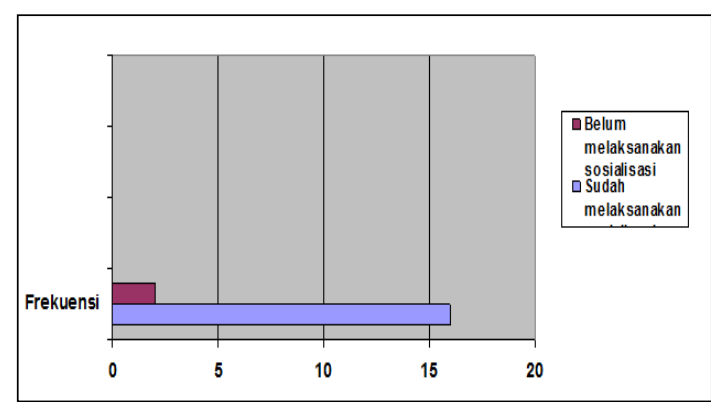

d.

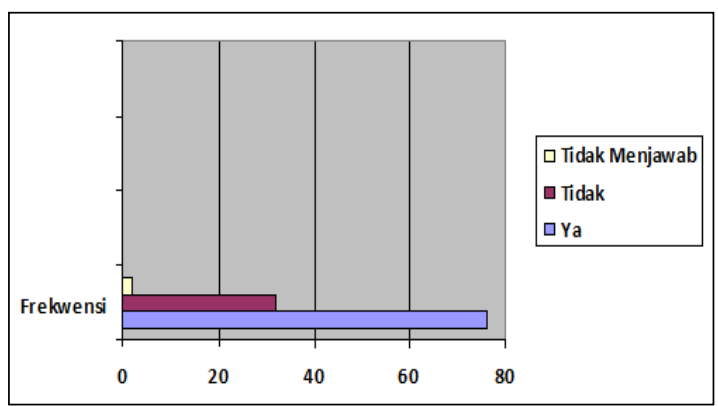

f.

Gambar 2.

a. Histogram Tanggapan Masyarakat Nelayan Untuk Menghentikan Kegiatan Illegal Fishing

b. Histogram Tanggapan nelayan apabila dilibatkan dalam pertemuan mengenai penanganan illegal fishing

c. Histogram Tentang Pengetahuan Nelayan Tentang UU Perikanan

d. Histogram Pernyataan Petugas Pengawas Perikanan Dalam Kegiatan Sosialisasi Undang-Undang Perikanan Kepada Masyarakat Nelayan

e. Histogram Hasil Sosialisasi Undang-undang Perikanan Oleh Petugas Perikanan

f. Histogram Nelayan Yang Pernah Melihat Illegal Fishing Di Daerahnya 
Banyakya izin yang telah diberikan oleh Dinas Kelautan dan Perikanan, baik Provinsi maupun Kabupaten/Kota yang kerap menyimpang dari peraturan perundang-undangan, khususnya terkait dengan asal usul kapal/bendera kapal, cek fisik kapal, ketentuan Anak Buah kapal (ABK), daerah penangkapan dan pelabuhan pangkalan membuka peluang besar terjadinya illegal fishing. Hal ini sengaja dilakukan karena euforia otonomi dan mengejar pendapatan asli darah (PAD).

Melalui kuesioner dan wawancara diperoleh data bahwa 55,6\% Pengawas di bidang Perikanan mengatakan bahwa kelemahan dalam penanganan illegal fishing disebabkan oleh lemahnya penegakan hukum dan $44,4 \%$ karena faktor kebijakan anggaran dan minimnya aparat pengawas Gambar 14.

Palang pintu penegakan hukum ada di Pengadilan. Apabila tuntutan pengadilan rendah,

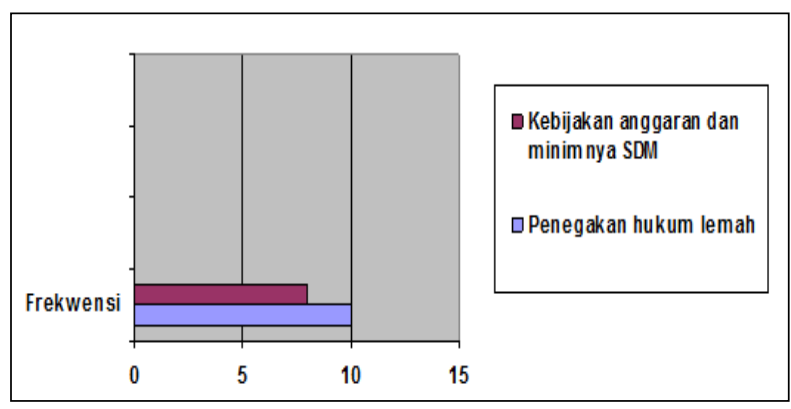

a. maka pengawasan, penangkapan, penyelidikan dan penyidikan tidak ada gunanya dan hal tersebut tidak akan membuat jera terhadap pelakunya. Jika keadaan seperti ini terjadi akan membuat institusi dan sistem pengawasan resmi tidak efektif. Dalam penelitian ini $77,78 \%$ pengawas perikanan mengatakan penanganan kasus oleh aparat kejaksaaan masih lemah, baru 22,22\% mengatakan bahwa perlu ada jaksa khusus bidang perikanan (Gambar 5).

Illegal fishing merupakan salah satu kejahatan ekonomi yang merugikan keuangan negara, khususnya di perairan Provinsi Maluku Utara, kegiatan illegal fishing cukup rawan dan sangat memprihatinkan. Selanjutnya dari hasil kuesioner dan wawancara diperoleh data bahwa 18 orang Pengawas Perikanan atau 100\% responden mengatakan tuntutan jaksa terlalu rendah dan tidak sesuai dengan kerugian negara yang ditimbulkan akibat illegal fishing.

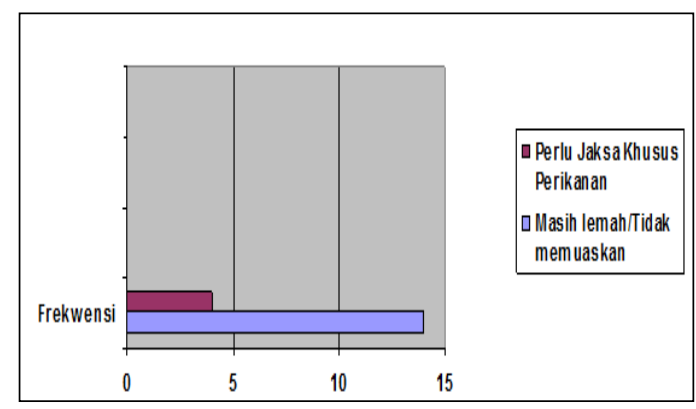

b.

Gambar 3.

a. Histogram Tanggapan Aparat Pengawas Mengenai Kelemahan Dalam Penangan Illegal Fishing di Provinsi Maluku Utara

b. Histogram Tanggapan Aparat Pengawas Perikanan Mengenai Penanganan Kasus Illegal Fishing oleh Kejaksaan Republik Indonesia

\section{KESIMPULAN DAN SARAN}

\subsection{Kesimpulan}

1. Dinas Kelautan dan Perikanan Provinsi Maluku Utara memiliki sarana dan prasarana yang diperuntukan untuk pengawasan sumberdaya ikan di samping itu melakukan kegiatan- kegiatan seperti pengawasan sumberdaya ikan, baik melalui kegiatan patroli di laut maupun pengawasan di pelabuhan, melakukan penegakan hukum oleh aparat pengawas bidang perikanan, sosialisasi sistem pengawasan berbasis masyarakat (SISWASMAS) namun pelanggaran tetap tinggi sehingga memberikan kesan ketidak efektifan atau tidak optimalnya kegiatan pengawasan yang dilaksanakan dalam pencegahan dan penanganan illegal fishing.
2 Tingkat partisipasi nelayan di Provinsi Maluku Utara dalam pengawasan sumberdaya perikanan cukup tinggi, hal ini dapat dilihat dari sikap nelayan yang sebagian besar akan melaporkan ke aparatur pengawas apabila melihat kegiatan illegal fishing, akan menegur dan menasehati, serta pernah mendiskusikan masalah illegal fishing dengan temannya dan mengatakan bahwa mereka bersedia kalau dilibatkan dalam rapat yang membahas mengenai illegal fishing. Namun partisipasi masyarakat nelayan di Maluku Utara dalam pengawasan sumberdaya perikanan terbatas pada daerah pesisir pantai akibat struktur armada penangkapan ikan yang jangkauannya terbatas pada daerah pesisir.. 
3. Kegiatan pengawasan dan penegakan hukum oleh aparat pengawas bidang perikanan di Provinsi Maluku Utara belum optimal, disebabkan karena minimnya aparat pengawas di bidang perikanan, sehingga belum dapat menjangkau seluruh wilayah perairan yang menjadi kewenangan pengelolaan perikanan Pemerintah Daerah Provinsi Maluku Utara, lemahnya kebijakan anggaran serta tuntutan dan putusan pengadilan terlalu rendah dan tidak sesuai dengan kerugian negara yang ditimbulkan akibat illegal fishing.

\subsection{Saran}

Saran yang perlu disampaikan terkait dengan kegiatan pengawasan sumberdaya perikanaan adalah;

1. Mengadakan kapal patroli yang layak untuk menjangkau wilayah pengelolaan Perikanan Provinsi Maluku Utara serta untuk peningkatan jumlah dan intensitas patroli di Laut.
2. Perlu segera melaksanakan pelayanan Surat Laik Operasional (SLO) di beberapa Kabupaten yang meliputi; Kabupaten Kepulauan Sula, Halmahera Tengah, Halmahera Timur, Halmahera Barat dan Pulau Morotai.

3. Untuk memberdayakan masyarakat nelayan dalam pengawasan sumberdaya perikanan (SISWASMAS) atau menjadikan nelayan sebagai bagian dari pengawasan atau sebagai informan di daerah penangkapan, maka perlu pengkajian agar masyarakat nelayan di Maluku Utara diberikan bantuan armada penangkapan ikan dengan ukuran di atas 30 GT agar mereka dapat melakukan pencegahan dan mengusir pelaku illegal fishing dari Perairan Maluku Utara.

4. Perlu adanya penambahan tenaga PPNS Perikanan di Provinsi Maluku Utara.

5. Perlu adanya peningkatan anggaran untuk kegiatan Pengawasan sumberdaya Perikanan di Provinsi Maluku Utara.

\section{DAFTAR PUSTAKA}

Alsa. (2002). Badan Kepegawaian Negara 2002, Metodologi Penelitian. Diambil tanggal 12 Nopember 2008 dari situs World Wide Web http://www.bkn.go.id

Wahyudin, A. (2008). Penegakan Hukum. Diambil tanggal 10 Nopember 2008 dari situs World Wide Web http://www.solusihukum.com

Azizy, A. (2005). Masalah Hukum dan Illegal fishing. Diambil tanggal, 10 Nopember 2008 dari situs World Wide Web http://www.sinarharapan.co.id

Bisri, I. (2004). Sistem Hukum Indonesia. Edisi ke-2. Jakarta: Penerbit Raja Grafindo Persada.

Burhanuddin, I. (2008). Jurusan Ilmu Kelautan-FIKP Unhas. Diambil tanggal, 10 Desember 2008 dari situs World Wide Web http://www.sinarharapan.co.id

Darmawan. (2006). Analisis Kebijakan Penanggulangan IUU-Fishing Dalam Pengelolaan Perikanan Tangkap Indonesia. Sekolah Pascasarjana Institut Pertanian Bogor.

Dinas Perikanan dan Kelautan Provinsi Maluku Utara. (2007). Laporan Tahunan 2007. Ternate : Pemerintah Provinsi Maluku Utara.

Direktorat Jendral P2SDKP. (2008). Kebijakan dan Program Pengawasan dan Pengendalian Sumberdaya Kelautan dan Perikanan. Diambil tanggal, 15 Nopember 2008 dari situs World Wide Web http://www.dkp.go.id

E. Utrecht, A. Tusaoh, A. (1986). Pengantar Ilmu Hukum. Fakultas Hukum Universitas Sam Ratulangi Manado. Makalah yang tidak dipublikasikan.

Faisal. S. (1995). Format-Format Penelitian Sosial, Dasar-Dasar dan Aplikasi. Jakarta : Raja Grafindo Persada.

FAO (Food Agriculture Organitation). 1995. Tatalaksana untuk Perikanan Yang Bertanggung Jawab.Tim Deptan, Penerjemah; Jakarta: FAO, Deptan, JICA. Terjemahan dari: Code of Conduct for Responshible Fisheries

Mochtar. (2006). Aksi Illegal fishing Kapal Asing Makin Marak, Tak Bisa Ditangkap. Diambil tanggal, 10 Nopember 2008 dari situs World Wide Web http://www.p2sdkpkendari.com

Nikijuluw, V. (2008). Dimensi Sosial Ekonomi Perikanan Ilegal (Blue Water Crime). Jakarta : Penerbit PT. Pustaka Cidesindo.

Peraturan Pemerintah Nomor 24 Tahun 2006 tentang Pengangkatan dan Pemberhentian Hakim Adhock Perikanan. Jakarta : Biro Hukum dan Organisasi Setjen Departemen Kelautan dan Perikanan 2008 
Siagian dalam Muchsan. (1992). Pengawasan terhadap aparatur Pemerintah Jakarta : Penerbit PT. Pustaka Cidesindo.

Solichin. (2005). Menyangsikan Pemberantasan Illegal fishing. Diambil tanggal, 10 Nopember 2008 dari situs World Wide Web http://www. ikanbijak.com

Sulistiyo. (2007). Penegakan Hukum. Diambil tanggal 19 Nopember 2008 dari situs World Wide Web http://www.solusihukum.com

Sularso. (2007). Permasalahan IUU fishing. Diambil tanggal 10 Nopember 2008 dari situs World Wide Web http://www. dkp.go.id

Sudirman. (2006). Melegalkan Partisipasi Masyarakat Dalam Kebijakan. Diambil tanggal 10 Nopember 2008 dari situs World Wide Web http://www.cifor.cgiar.org

Slamet. (1989). Konsep-Konsep Dasar Partisipasi Sosial, Yogyakarta : Pusat Antar Universitas-Studi Sosial. Universitas Gajah Mada. Yogyakarta. Makalah yang tidak dipublikasikan.

TIM REDAKSI FOKUSMEDIA. (2005). Tiga Undang-Undang Sumber Daya Alam : Undangundang Nomor 31 Tahun 2004 tentang Perikanan. Bandung. 